\title{
Antarctic Science
}

Published on behalf of Antarctic Science Ltd, Cambridge

\section{Editors}

David W. H. Walton, British Antarctic Survey, Cambridge, UK Alan P. M. Vaughan, British Antarctic Survey, Cambridge, UK

Christina L. Hulbe, Portland State University, USA

Antarctic Science provides a truly international forum for the broad spread of studies that increasingly characterize scientific research in the Antarctic. The journal attracts papers from all countries currently undertaking Antarctic research. Whilst emphasising interdisciplinary work, the journal publishes papers from environmental management to biodiversity, from volcanoes to icebergs, and from oceanography to the upper atmosphere. No other journal covers such a wide range of Antarctic scientific studies.

\section{Price information} is available at: http://journals.cambridge.org/ans

\section{Free email alerts}

Keep up-to-date with new material - sign up at http://journals.cambridge.org/ans-alerts

To subscribe contact

Customer Services

in Cambridge:

Phone $+44(0) 1223326070$

Fax $+44(0) 1223325150$

Email journals@cambridge.org

in New York:

Phone +1 (845) 3537500

Fax +1 (845) 3534141

Email

subscriptions_newyork@cambridge.org 


\section{Environmental Conservation}

International Journal of Interdisciplinary Environmental Science

Published for the Foundation for Environmental Conservation

\section{Editor}

Nicholas V. C. Polunin, University of Newcastle, UK

Environmental Conservation is one of the longeststanding, most highly-cited of the interdisciplinary environmental science journals. It includes research papers, reports, comments, subject reviews, and book reviews addressing environmental policy, practice, and natural and social science of environmental concern at the global level, informed by rigorous local level case studies. The journal's scope is very broad, including issues in human institutions, ecosystem change, resource utilisation, terrestrial biomes, aquatic systems, and coastal and land use management. Environmental Conservation is essential reading for all environmentalists, managers, consultants, agency workers and scientists wishing to keep abreast of current developments in environmental science. Selected papers are made freely available online as part of EC Perspectives.

\section{Price information}

is available at: http://journals.cambridge.org/enc

\section{Free email alerts}

Keep up-to-date with new material - sign up at http://journals.cambridge.org/enc-alerts

To subscribe contact

Customer Services

in Cambridge:

Phone $+44(0) 1223326070$

Fax $+44(0) 1223325150$

Email journals@cambridge.org

in New York:

Phone +1 (845) 3537500

Fax +1 (845) 3534141

Email

subscriptions_newyork@cambridge.org 


\section{THE MARINE BIOLOGICAL ASSOGIATION OF THE UNITED KINGDOM}

\section{TERMS OF MEMBERSHIP FOR 2013}
Annual members, receiving the Journal - online only, per annum
$£ 55.00^{*}$
$£ 95.00^{*}$
Annual members, receiving the Journal - print only, per annum
£115.00*
Annual members, receiving the Journal - print and online, per annum
$£ 35.00^{*}$
Annual members, without the Journal, per annum
Corporate members, receiving the Journal - online only, per annum
$£ 360.00$
Corporate members, receiving the Journal - print and online, per annum
$£ 425.00$
$£ 30.00$
Student members, with the Journal - online only, per annum (non-voting)
$£ 45.00$
Student members, with the Journal - print only, per annum (non-voting)
$£ 20.00$

The Association is a registered charity and was founded in 1884 to promote accurate researches leading to the advancement of zoological and botanical science and to increase our knowledge of the food, life, conditions and habits of British fish. The work of the Association is controlled by the Council elected annually by its subscribing members.

The Marine Biological Association, under the direction of its Council, has undertaken research in all branches of marine science and many of the results have been published in this Journal. An account of the history of the first hundred years of the Association and Journal may be found in Volume 67 (pp. 463 and 465). Summaries of the activities and research of the Association are given annually in the Report of the Council, sent to members in April, and to other subscribers with a later issue of the $7 M B A$.

Since its foundation the Association has been supported by grants from Research Councils and by subscriptions and donations from private members, universities, learned societies, the Fishmongers' Company and other public bodies.

The Plymouth Laboratory was opened in June 1888 and, since that date, considerable additions have been made to the buildings, including a library, resource centre, extensive laboratory accommodation and seawater facilities.

In 1988 an agreement was reached between the MBA Council and the Natural Environment Research Council (NERC) to merge a large part of the Plymouth Laboratory with the NERC's Institute for Marine Science which had been in Plymouth since 1971. This new institute was called the Plymouth Marine Laboratory (PML) based at both Citadel Hill and West Hoe sites. In 2001 the MBA and PML re-established separate identities funded by Grants-in-aid from NERC. The Association and the research programme are based entirely at the Citadel Hill Laboratory. The building is shared with SAHFOS (Sir Alister Hardy Foundation for Ocean Science).

The Marine Biological Association retains the lease of the building on Citadel Hill and continues as a very active scientific learned society with a large international membership. The MBA manages a research programme carried out by research fellows (partly funded by NERC) together with scientific visitors, publishes an International Journal, Annual Report, Newsletters and organizes scientific meetings.

Subscriptions can be paid by cash/cheque, direct debit from a UK bank account or credit card. *Subscriptions are reduced by $£^{5}$ per annum if paying by direct debit.

Members of the Association have the following rights and privileges: they elect the Officers and Council annually; they are entitled to receive the Journal of the Association at the members' rate; they receive the biannual Newsletter, they have the option to apply to the Director for research facilities at the laboratory; and they have access to the resources in the library at Plymouth during working hours. Corporate members have significant additional rights and privileges, details of which can be supplied on request. Student members do not have voting rights. The Commissioners of Inland Revenue have approved the Association for the purposes of Section 16, Finance Act, 1958, and that the whole of the annual subscriptions paid by a member who qualifies for relief under the section will be allowable as a deduction from his emoluments assessable to income tax.

All correspondence should be addressed to: The Membership Secretary, Marine Biological Association, The Laboratory, Citadel Hill, Plymouth, PL1 2PB, UK (Tel: +44 (0) 1752 633207; Fax: +44 (0) 1752 633102; e-mail: membership@mba.ac.uk).

\section{PUBLISHED BY THE PRESS SYNDICATE OF THE UNIVERSITY OF CAMBRIDGE} The Pitt Building, Trumpington Street, Cambridge, CB2 1RP, United Kingdom

This journal issue has been printed on FSC-certified paper and cover board. FSC is an independent, non-governmental, not-for-profit organization established to promote the responsible management of the world's forests. Please see www.fsc.org for information.

\section{GAMBRIDGE UNIVERSITY PRESS}

The Edinburgh Building, Cambridge, CB2 2RU, United Kingdom 32 Avenue of the Americas, New York, NY 10013-2473, USA 477 Williamstown Road, Port Melbourne, VIC 3207, Australia C/ Orense, 4, planta 13, 28020, Madrid, Spain

Dock House, The Waterfront, Cape Town 8001, South Africa 


\section{VOLUME 93.3 MAY 2013}

\section{CONTENTS}

Neves, R.A.F., Echeverria, C.A., PessoA, L.A., Paiva, P.C., Paranhos, R. \& Valentin, J.L. Factors influencing spatial patterns of molluses in a eutrophic tropical bay

ShoRT, J., MetaxAs, A. \& DAlGL, R.M. Predation of larval benthic invertebrates in St George's Bay, Nova Scotia

$\mathrm{X}, \mathrm{G}$., L, Y., HE, C. \& XU, H. Congruency analysis to determine potential surrogates of littoral macroinvertebrate communities: a case study in intertidal

ecosystems of northern Yellow Sea

Centurión, R. \& Gappa, J.L. Benthic biodiversity off the eastern mouth of the Strait of Magellan (Argentina, south-west Atlantic)

QuiNTAS, P., MorelRA, J. \& Troncoso, J.S. Distribution patterns of molluscan fauna in seagrass beds in the Ensenada de 0 Grove (Galicia, north-western Spain)

SChMDT-RhaEsA, A., POHLE, G., Gaudette, J. \& BuRDEtT-CoutTs, V. Lobster (Homarus americanus), a new host for marine horsehair worms (Nectonema agile,

Nematomorpha)

Soler-Membrives, A., Arango, C.P., Cuadrado, M. \& Munilla, T. Feeding biology of carnivore and detritivore Mediterranean pycnogonids

Wu, L., GAO, Q., WANG, G. \& LU, Y. Diel variations in Centropages tenuiremis (Copepoda) feeding, spawning and its relationship with temperature

Corgosinho, P.H.C. \& SchIzas, N.V. Archeolourinia shermani, a new genus and species of Louriniidae (Copepoda: Harpacticoida) from a Caribbean mesophotic zone

FruTos, I. \& SorBE, J.C. Leucothoe cathalaa sp. nov. (Crustacea: Amphipoda: Leucothoidae), a new bathyal benthic species from the Le Danois Bank

('El Cachucho' Spanish MPA), southern Bay of Biscay

Pardal-Souza, A.L. \& PinhelRo, M.A.A. Relative growth and reproduction in Achelous spinicarpus (Crustacea: Portunidae) on the south-eastern continental shelf of Brazil

Romero-RooriGuez, J. \& Romain-Contreras, R. Population structure and reproduction of the seagrass shrimp Hippolyte zostericola (Decapoda: Hippolytidae) at Laguna de Términos, Campeche, Mexico

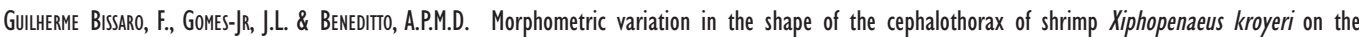
east coast of Brazil

BarRos-Avves, S.D.P., ALves, D.F.R. \& COBO, V.J. Comparison of the population biology of Epialtus bituberculatus from two rocky shores with distinct hydrodynamic patterns

TuRNer, L.M., Hallas, J.P., SMith, M.J. \& MorRRI, S. Phylogeography of the Christmas Island blue crab, Discoplax celeste (Decapoda: Gecarcinidae) on Christmas Island, Indian Ocean

Peiró, D.F., Bazza, J.A. \& MantelatTo, F.L. Host-use pattern and sexual dimorphism reveals the mating system of the symbiotic pea crab Austinixa aidae (Crustacea: Brachyura: Pinnotheridae)

CARMONA-SǗrez, C.A. Population dynamics and reproductive aspects of the decorator crab Microphrys bicornutus (Crustacea: Brachyura: Majidae) in an extreme shallow Thalassia complex

Gomes, A.P.P., Keunecke, K.A., SILVA, JR D.R.D. \& VIanna, M. Modulating reproduction of Penaeidae shrimps: ecological responses of two sympatric species (Decapoda: Dendrobranchiata) on south-eastern Brazilian coast

Nye, V., CopleE, J., PLouviez, S. \& Dover, C.L.V. A new species of Lebbeus (Crustacea: Decapoda: Caridea: Hippolytidae) from the Von Damm Vent Field, Caribbean Sea Simões, S.M., Castillho, A.L., Fransozo, A., Negreiros-Fransozo, M.L. \& Costa, R.C.D. Distribution related to temperature and salinity of the shrimps

Acetes americanus and Peisos petrunkevitchi (Crustacea: Sergestoidea) in the south-eastern Brazilian littoral zone

Shinozani-Mendes, R.A., Sulva, J.R.F., Santander-Neto, J. \& Hazin, F.H.V. Reproductive biology of the land crab Cardisoma guanhumi (Decapoda: Gecarcinidae) in north-eastern Brazil

VICENTE, C.S., Frutos, I. \& SORBE, J.C. Mysidopsis cachuchoensis sp. nov. (Crustacea: Mysida: Mysidae), a new suprabenthic mysid from bathyal soft-bottoms of the Le Danois Bank (southern Bay of Biscay)

Hirose, G.L., Fransozo, V., Tropea, C., López-Greco, L.S. \& NeGrelRos-Fransozo, M.L. Comparison of body size, relative growth and size at onset sexual maturity of Uca uruguayensis (Crustacea: Decapoda: Ocypodidae) from different latitudes in the south-western Atlantic

AoK, M. \& Wada, K. Genetic structure of the wide-ranging fiddler crab Uca crassipes in the west Pacific region

Pulgar, J., Aldana, M., Alyarez, M., Garcla-Hudobro, R., Molina, P., Morales, J.P. \& Pulgar, V.M. Upwelling affects food availability, impacting the morphological and molecular conditions of the herviborous limpet Fissurella crassa (Mollusca: Archeogastropoda)

Molen, S.V.D., Márquez, F., IDaszkin, Y.L. \& ADAMI, M. Use of shell-shape to discriminate between Brachidontes rodriguezii and Brachidontes purpuratus species (Mytilidae) in the transition zone of their distributions (south-western Atlantic)

Suárez-Moo, P.D.J., Calderon-Agulera, L.E., Reyes-Bonlla, H., Diaz-Erales, G., Castañeda-Fernandez-de-Lara, V., Aragón-Noriega, E.A. \& Rocha-Olivares, A. Integrating genetic, phenotypic and ecological analyses to assess the variation and clarify the distribution of the Cortes geoduck (Panopea globosa)

Gonçalves, C.I. \& LOBo-DA-CunHA, A. Seasonal and starvation-induced changes on gonads and lipid reserves of the digestive gland of Nucella lapillus (Caenogastropoda)

Teso, V. \& Giménez, J. Sperm morphology of two species of Olivancillaria (Gastropoda: Olividae) from the south-western Atlantic

ORTIZ, N. Validation of macroscopic maturity stages of the Patagonian red octopus Enteroctopus megalocyathus

Cuccu, D., Mereu, M., CAU, A., PEsCI, P. \& CAU, A. Reproductive development versus estimated age and size in a wild Mediterranean population of Octopus vulgaris (Cephalopoda: Octopodidae)

Önsor, B., CEvLAN, B. \& Salman, A. Reproductive biology of the lentil bobtail squid, Rondeletiola minor (Cephalopoda: Sepiolidae) from the eastern Mediterranean 